\title{
A queer szubkultúra vizuális kódjai
}

\author{
A tradicionálisan férfiasnak vagy nôiesnek minôsített viselkedés
} nem velünk született, hanem a körülmények, szúkebb és tágabb környezetünk és a társadalmi elvárások hatására alakul ki. A tanult nemi szerepek kérdését és azok társadalmi vonatkozásait elsóként a genderelmélet tematizálta, míg a stabil biológiai nemek, társadalmi

nemek és szexualitások radikális megkérdójelezése elsốsorban a queer mozgalomhoz kapcsolódik. A nemek közötti éles határvonalak eltörlésének igénye pedig sajátos vizuális kódokat eredményez.

\footnotetext{
A
} serdülökor időszaka az autonóm, felnőtt én kialakulásának egyik legmeghatározóbb állomása. Erikson (2001) ezt az életszakaszt a pszichoszociális öndefiníció korának nevezni, amelynek egyik kiemelten fontos feladata a szexuális szerep és identitás személyiségbe való beépítése. A hagyományos férfi és női viselkedésminták azonban sokkal inkább kulturális meghatározottságúak, mint biológiai eredetủek, és erre a leghatározottabban a gender- és queer-elméletek mutattak rá.

A queer fogalma az 1990-es években kezdett megjelenni a társadalomtudományi diskurzusokban, elsősorban a gender (társadalmi nem) kérdéséhez kapcsolódóan. A feminista elmélet nyolcvanas évekbeli kulturális feminista ágából indult el a társadalmi nemek új, queer kritikája (Jagose, 2003. 14-15.). Az elmélet lényegi eleme a biológiai nem, a társadalmi nem és a szexuális vágy között tételezett koherencia megkérdőjelezése. A queer szembemegy a klasszikus stabilitás-modellel, amely a heteroszexualitást esszenciálisnak és eredendőnek tartja, és rámutat arra, hogy nem létezik semmiféle természetes, eleve adott szexualitás. Még a látszólag olyan evidens terminusokat is kétségbe vonja, mint a homoszexuális és heteroszexuális vagy a férfi és nő kategóriája.

Az erőteljes, eleve konfrontációt hordozó queer szó széleskörü elterjedése már önmagában egy határozott ellenállást jelenít meg, és a hagyományos modellek érvénytelenségét jelzi. A queer eredeti jelentése 'furcsa, különös', de sokáig leginkább a homoszexuálisokra vonatkozó szitokszóként jelent meg. Amikor a megbélyegző kifejezést a melegek magukra kezdik használni, elismerik a róluk szóló normatív társadalmi diskurzus megkerülhetetlenségét, ugyanakkor meg is törik a hagyományos beszédmódot, és ez újfajta kérdésfeltevést eredményez (Mészáros, 2014. 55-57.).

Elsősorban Althusser, Freud, Lacan, Saussure és Foucault munkássága adja azt a fogalmi keretet, amelyben a queer-elméletek létrejöttek (Jagose, 2003. 79-83.). A 20. században a látszólag magától értetődő, logikus Descartes-i identitás-meghatározás több szempontból is problematikussá vált. Megjelentek azok a posztstrukturalista elméletek, amelyek megkérdőjelezték a természetszerüleg racionálisnak és koherensnek tekintett identitást, és inkább annak átmeneti, kontextustól függő, feltételes jellegére hívták fel a figyelmet. Louis Althusser szerint nincs előzetesen létező szabad szubjektum, sőt magát a szubjektumunkat is az ideológia hozza létre. Sigmund Freud elmélete pedig lehetetlenné teszi, hogy a szubjektivitást továbbra is stabilnak és koherensnek tekintsük. A tudattalanról szóló elmélete egyértelmüen kétségbe vonja azt a feltételezést, hogy a 
szubjektum teljes és önmagát megismerni képes, illetve hogy a szexualitás és a nemi identitás velünk született lenne. Freud müveinek későbbi interpretációi - elsősorban a francia pszichoanalitikus, Jacques Lacan munkái - pedig egyenesen tanult, nem eleve adott dolognak tételezik a szubjektivitást. Ferdinand de Saussure pedig azt mondja, hogy a nyelv nem annyira tükrözi, mint inkább konstruálja a társadalmi valóságot. A privát, személyes és benső énről való fogalmainkat is a nyelven keresztül alkotjuk meg (Jagose, 2003. 79-83.). Michel Foucault gondolatai azok, amelyek a leginkább meghatározzák a mozgalom szellemi hátterét. A francia történész szerint a modern szubjektivitás különböző hatalmi hálózatok eredménye, és ezáltal a szexualitás sem egy természetes állapot, hanem a diskurzus terméke: „A szexualitást ugyanis nem valami természettől adott dologként kell elképzelni... Egyszerüen ezt a nevet adhatjuk egy bizonyos történelmi stratégiának és mechanizmusnak." (Foucault, 1999. 105),

A queer-elméletek egyik legjelesebb képviselője Judith Butler (1999), aki szakít a feminizmus nőiséget hangsúlyozó gesztusával, és a meleg mozgalmakra jellemző, védekező, a homoszexualitást mint természetes másságot kiemelö diskurzusával. Szerinte ugyanis mindkét kategória abba a diszkurzív hatalmi rendbe illeszkedik, amely létrehozza, és amelyet maga is megerősít épp azáltal, hogy harcol ellene. Butler megkérdőjelezi az összes olyan fogalmat, amely a szubjektumra és az identitásra vonatkoznak, hiszen azokat is a hatalmi diskurzusok hozzák létre. Azonban nem akarja a queer kifejezést sem újabb identitáskategóriává tenni, és ellenáll a queer-elmélet definiálásának is. Szerinte a társadalmi nem valójában nem a biológiai nem jele, nem abból következik, hanem inkább performatív jellegü. A test stilizált, ismétlődő gyakorlatai ezek, amelyek egy idő után valami eredeti, természetes benyomását keltik. Autentikus nemiség azonban nem létezik. A nem ilyen radikális megkérdőjelezése szerinte sokkal eredményesebb lehet a meleg mozgalmak korábbi stratégiáival szemben, mivel sokkal inkább képes dekonstruálni azt a heteroszexualitást, amely úgy tesz, mintha természetes lenne (Butler, 1999).

A stabil biológiai nemek, társadalmi nemek és szexualitások demisztifikálása, az identitás sokféle instabil álláspont konstellációjaként való felfogása a nemi szerepek tényleges liberalizálásához vezet. A queer közösség célja egy olyan csoport létrehozása, amelyet már nem a tagok és azok szexuális partnereinek a neme határoz meg. Queer az, aki annak vallja magát, aki felismeri és elutasítja a korlátozó identitás-meghatározások önkényességét (Süvecz, 2002). Éppen ezért a queer közösségekre nagyfokú nyitottság jellemző. Tagjai között homoszexuálisokat, biszexuálisokat vagy transznemüeket éppúgy megtalálhatunk, mint heteroszexuálisokat, hiszen a csoport szerves részévé válva ezek a címkék érvényüket vesztik.

A queerek vizuális reprezentációjának vizsgálatakor megkerülhetetlennek tünik a camp fogalma. A camp szó 'felszínes, giccses, talmi' értelmében már a 20. század elején megjelent; alapja egy francia zsargonszó, a „se camper”, ami kb. annyit tesz, mint ágálni, pöffeszkedni, magát túladagolni, megjátszani (Szőcs, 2008). Susan Sontag (1972) a túlfinomultság modern szemléletmódjaként, egyfajta esztéticizmusként határozza meg a campet. Annak módjaként, ahogy a világot esztétikai jelenségként értékeljük, nem szépsége, hanem stilizáltságának foka szerint. Ez a stilizáltság azonban nem csupán mủalkotások vagy hétköznapi tárgyak jellemzője lehet, hanem emberi magatartásformaként is értelmezhető, egyfajta világlátásként, a „nem-az-ami szereteteként”.

Sontag definiálja, és egyben tovább generálja a szó jelentését: egyrészt meghatározza azokat a kulcsfogalmakat (mint például a játékosság, a természetellenesség, az androgün, a glamour, a teatralitás vagy a giccs), amelyek köré a camp szerveződik; másrészt leszögezi, hogy a camp egy fluid kategória, melynek nincsen stabil jelentésalapja, kizárólagos értelme. Szorosan kötődik a posztmodern müvészetekhez és a popkultúrához. Sajátosan könnyed és frivol szemléletmód, a dolgok idézőjelbe tétele jellemzi. A stílus győzelme a tartalom felett, az esztétikáé a morál fölött és az iróniáé a tragédia fölött. Legfejlettebb 
megnyilvánulási formája a szecesszió, legtökéletesebb megtestesítője pedig Oscar Wilde és az általa képviselt dandy típusa (Süvecz, 2002).

Már Sontag is összefüggésbe hozta a homoszexualitást mint esztétikai kategóriát a camppel, de ez a szoros együttállás talán még nyilvánvalóbb a queerek esetében. A nemi szerepek közötti határok lebontása a hagyományosan férfias és nőies külső jegyek egymásban való feloldódását eredményezik, megteremtve ezzel az abszolút androgün megjelenést. Céljuk tehát nem az ellenkező nem markáns stílusjegyeinek, attitüdjeinek elsajátítása vagy épp imitálása (ellentétben pl. a transzvesztitákkal), hanem a nemek közötti éles határvonalak eltörlése.
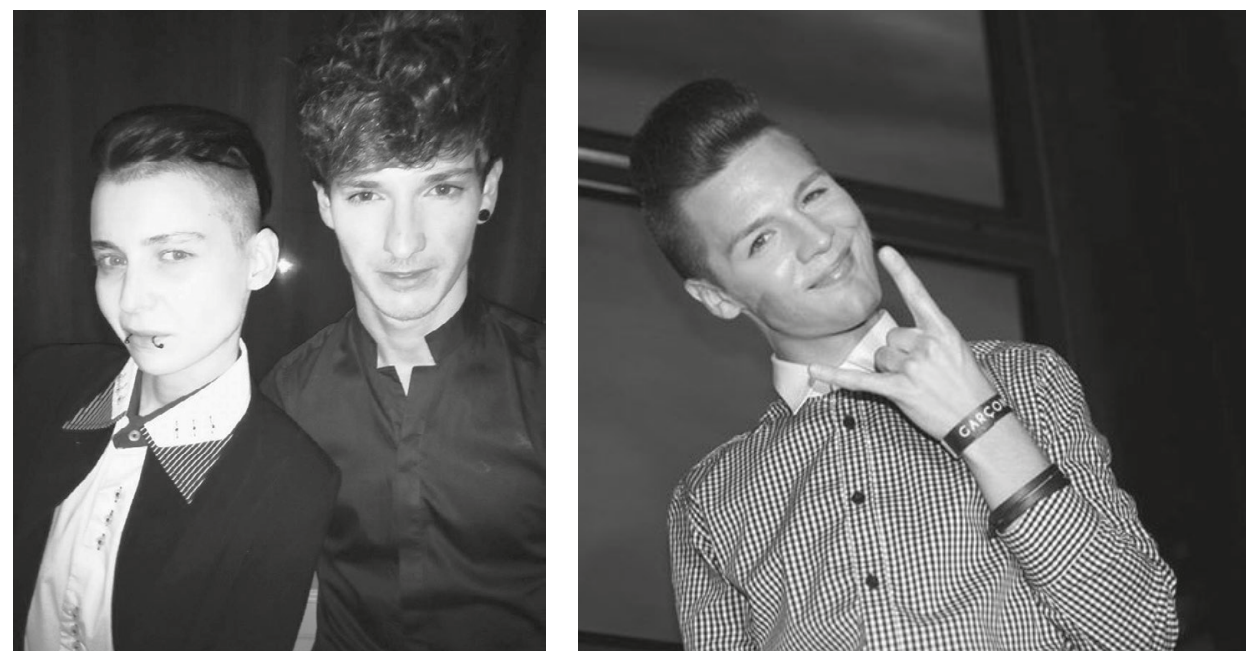

1-2. kép. Queer fiatalok az egyik legnépszerübb ruhadarabban: elegáns ingben (Képek forrása:1. kép: a szerzö saját képe; 2. kép: http://www.garconsbudapest.com/)

Megjelenésüket tekintve érvényüket vesztik az olyan hagyományos kategóriák, mint a nőies vagy a férfias. Mindkét nem stíluskellékeiből, ruhadarabjaiból, kiegészítőiből válogatnak egyszerre. A természetes hatású, szinte láthatatlan smink például éppúgy elengedhetetlen a férfiak számára, mint a gondosan elkészített frizura.

A queerek számára a tökéletes megjelenés kiemelt fontosságú, hiszen esetükben ez a vizuális önreprezentáció lényeges eleme. Figyelemmel kísérik és követik a divat legújabb irányzatait, és sok időt, energiát fordítanak a gondosan megkomponált külső létrehozására. A queer ideál az elegáns és egyben stílusos ember. Nemre való tekintet nélkül jellemző viseletük az ing és a zakó, sokszor nyakkendővel és mellénnyel, sőt olykor kalappal kiegészítve. A legaktuálisabb trendek mellett tehát megjelenésük fó inspirációs forrása az Oscar Wilde-féle dandy stílus. 

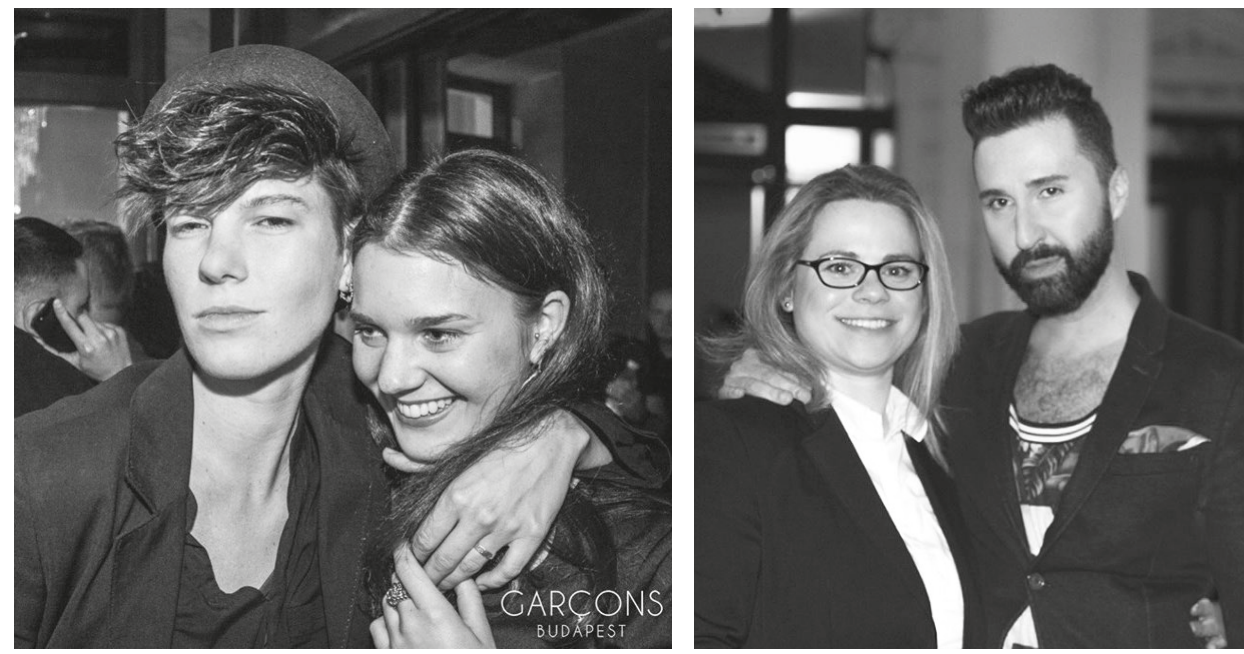

3-4. kép. Queer megjelenés a dandy stílus jegyében (Képek forrása: http://www.garconsbudapest.com/)

De nem ritka az extravagáns, meghökkentő, már-már jelmezszerü kinézet sem.
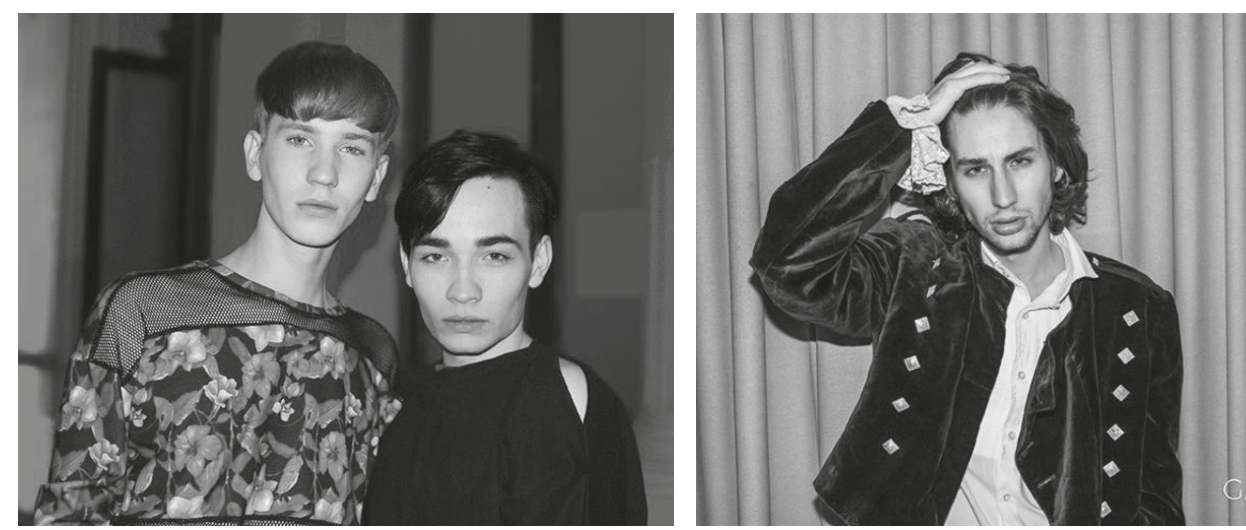

5-6. kép. Queerek teátrális öltözékben (Képek forrása: http://www.garconsbudapest.com/)

Az ilyen jellegü megjelenés azonban leginkább a kifejezetten queereknek szervezett, tematikus partikon gyakori. Ezek azok az alkalmak, amikor félelem nélkül, nyíltan felvállalhatják nemi identitásukat, valódi arcukat, anélkül, hogy ennek bármiféle negatív következménye volna. Míg pl. San Franciscóban külön kultúrközpont müködik a queer közösség és müvészet támogatásáért (Queer Cultural Center: http://www.queerculturalcenter.org/), addig nálunk ezek az események jelentik számukra a közösségépítés szinte egyetlen lehetőségét.

A queer partik helyszínei és díszletei is sokat elárulnak a közösség ízlésvilágáról és stíluspreferenciáiról. Az események általában olyan illusztris helyeken kerülnek megrendezésre, mint a Tőzsdepalota, a Vörösmarty téri Kaszinó vagy a Belgrád rakpart egyik impozáns épülete. Jellemzően 19. század végi vagy 20. század eleji, nagy múltú, egyedi építészeti megoldásokkal bíró épületek ezek. A gazdagon díszített külső és belső tér pedig remek háttérként szolgál ezekhez a már-már báli hangulatot időző parikhoz. 

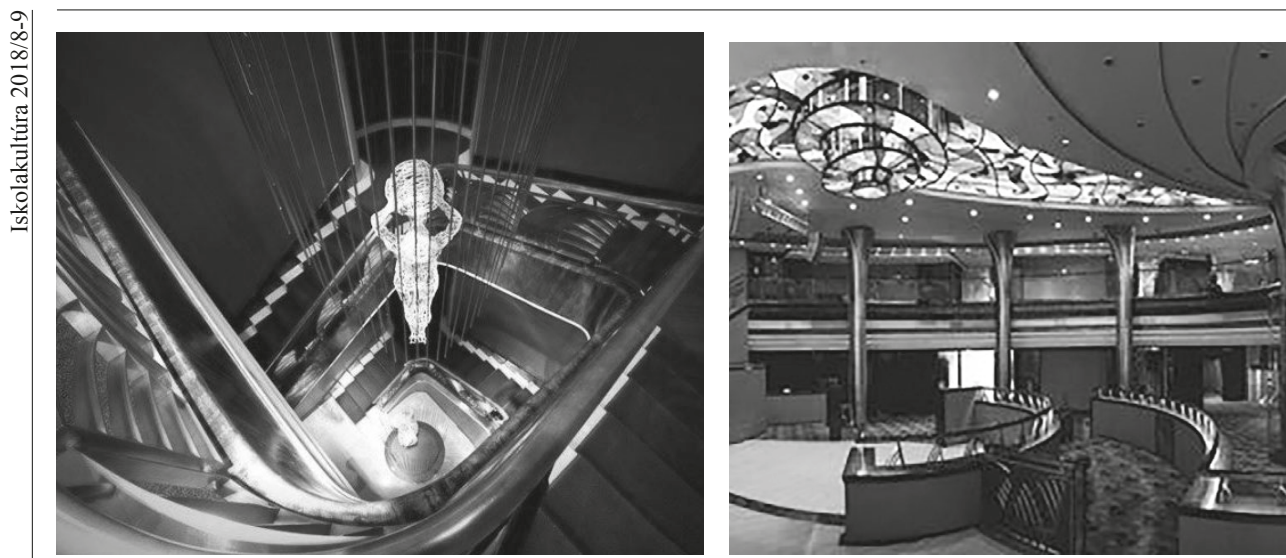

7-8. kép. A queer rendezvények gyakori helyszine az illusztris Kaszinó (Képek forrása: http://www.garconsbudapest.com/)
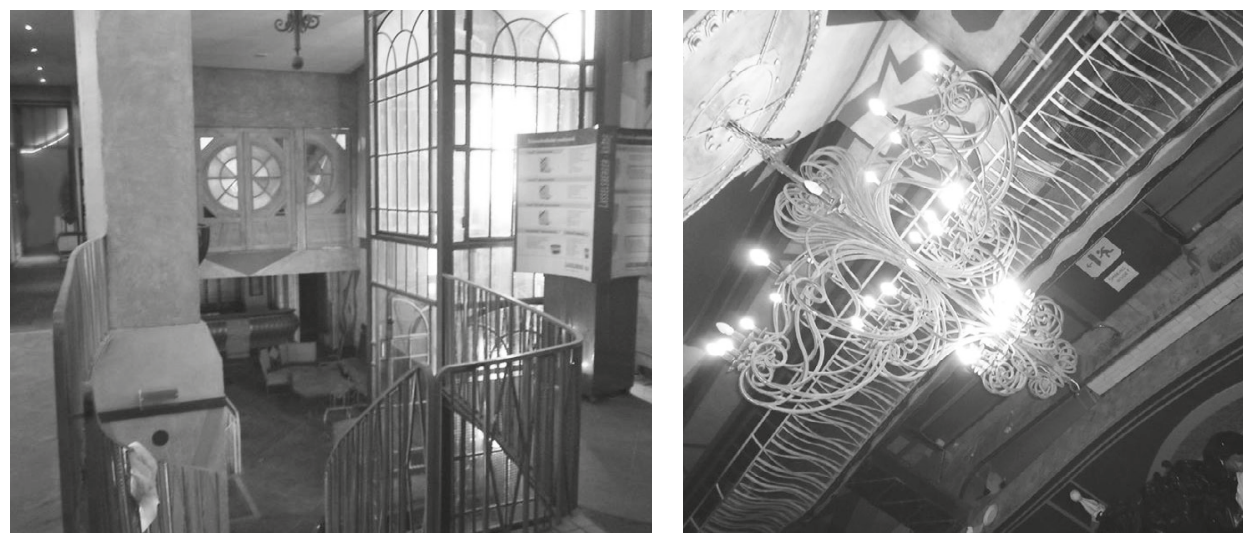

9-10. kép. A Belgrád rakpart egyik épülete, eklektikus belsö terekkel (a szerzö saját képei)

A camp tehát nemcsak a queerek megjelenésében tükrözödik, hanem az általuk kedvelt szórakozó- és közösségi helyek kialakításában is. Az egyedi, elegáns és teátrális belső terek általában a szecesszió stílusjegyeit viselik magukon, de nem ritka az eklektikus berendezés sem. A helyek különleges atmoszférája, sajátos hangulata leginkább az orfeumok világát idézi.

A színházi díszletre emlékeztető berendezés azonban nemcsak a szórakozóhelyekre jellemző, hanem akár a lakberendezésre is hatással lehet; hiszen a közvetlen környezetünket is alakíthatjuk a glamour jegyében. A tárgyak pedig a díszítőfunkción túl jelképek is egyben; egy olyan stílus és egyben világnézet szimbólumai, amely minden jelenséget esztétikai szempontból értékel, és amelyben a tradicionális férfi-nő oppozíció érvényét veszti. Így kerülhet egymás mellé egy fiúszoba enteriőrjében a mü kandallópárkány, a női mellszobor és egy ikonikus Marilyn Monroe-kép replikája. 


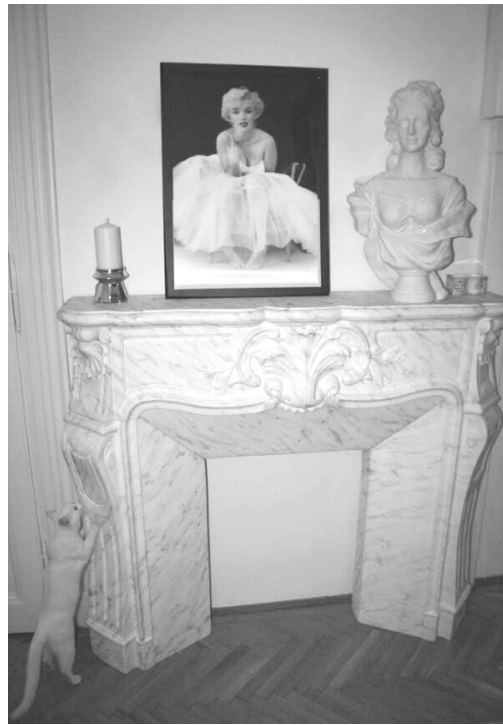

11. kép. Egy queer fiúszoba enteriőrje (A kép forrása: a szerző saját képe)

Már 1949-ben Simone de Beauvoir rámutatott a társadalmi nemi szerepek, a gender létezésére. Szállóigévé vált mondata: „Az ember nem születik nőnek, hanem azzá válik” (Beauvoir 1969. 197.) rávilágít arra a queer-elméletek alapját képező gondolatra, hogy a férfiasnak és nőiesnek minősített viselkedés nem velünk született, hanem a körülmények, szükebb és tágabb környezetünk és a társadalmi elvárások hatására alakul ki. Biológiai tényezők nem magyarázzák vagy határozzák meg a nemi szerepkülönbségeket: mindenkiben vannak férfiasnak vagy nőiesnek tartott tulajdonságok, ezek aránya pedig egyénenként változó. A nemi szerepkülönbségek viszonylagosak, egyre inkább csökkenő tendenciát mutatnak, már-már elmosódóban vannak (Szilágyi, 2010). A férfiasság és nőiesség fogalmát tehát érdemes átértékelnünk, és korszerübb tartalommal megtöltenünk.

A serdülőkor az az időszak, amikor az identitás megszilárdul. A személyiségfejlődés során ekkor alakul ki az a nemi, társadalmi szereptudat, amely a későbbiekben az egyén cselekvését, viselkedését és jellemét is nagymértékben meghatározza. A fejlődésnek ebben a szakaszában a serdülö különféle viselkedésformákat, érdeklődési irányokat, ideológiákat fedez fel és próbál ki, hogy ki tudja választani azokat, amelyek leginkább illenek a személyiségéhez (Cole \& Cole, 1998).

Fontos, hogy a serdülő maga válasszon saját értékpreferenciái alapján, és ne kényszerüljön olyan szerepekbe, amelyekkel nem képes azonosulni. A hagyományos férfias és nőies nemi szerepek, illetve az ezekkel kapcsolatos elvárások történelmileg igencsak változóak és szociokulturálisan viszonylagosak. A tradicionális nemi szerepektől való kisebb-nagyobb mértékü eltérés pedig egyre gyakoribb jelenség.

\section{Befejezés}

Az utóbbi évtizedekben egyre inkább előtérbe került a férfi és női szerepek és az ezekhez füződő társadalmi elvárások kulturális meghatározottságának problémája. Elsősorban Freud, Lacan és Foucault gondoltai nyomán létrejövő queer-elméletek lényegi eleme a biológiai nem, a társadalmi nem és a szexuális vágy között tételezett koherencia megkérdőjelezése. A nemi szerepek közötti határok lebontása pedig a hagyományosan férfias 
és nőies külső jegyek egymásban való feloldódását eredményezte. A queerek vizuális reprezentációjának meghatározó eleme a camp, amelyet Susan Sontag egyfajta sajátos esztéticizmusként definiált. A camp nemcsak a queerek megjelenésében tükröződik, hanem az általuk kedvelt szórakozó-, közösségi és lakóhelyek kialakításában is.

\section{Irodalom}

Butler, J. (1999). Gender Trouble: Feminism and the Subversion of Identity. New York - London: Routledge. Utolsó letöltés: 2018. július 10.

Cole, M. \& Cole, S. R. (1998). Fejlödéslélektan. Budapest: Osiris Kiadó.

De Beauvoir, S. (1969). A második nem. Budapest: Gondolat Kiadó.

Erikson, E. (2001). Az emberi fejlődés nyolc szakasza. In Szakács Ferenc és Kulcsár Zsuzsanna (szerk.), Személyiségelméletek. Budapest: ELTE Eötvös Kiadó. $127-138$.

Foucault, M (1999). A szexualitás története I. Budapest: Atlantisz Kiadó.

Jagose, A. (2003). Bevezetés a queer-elméletbe. Budapest: Új Mandátum Könyvkiadó.

Mészáros Gy. (2011). Ifjúsági szubkultúrák és „,szubkulturális pedagógia" egy iskolai etnográfia fényében. Iskolakultúra, 21(1), 22-38.
Mészáros Gy. (2014). Szubkultúrák és iskolai nevelés. Veszprém: Iskolakultúra.

Rácz J. (1998). Ifjúsági (szub)kultúrák, intézmények, devianciák. Válogatott tanulmányok. Budapest: Scientia Humana.

Sontag, S. (1972). A pusztulás képei. Budapest: Európa Kiadó.

Süvecz, E. (2002). Jegyzetek a Queer láthatóságáról. Balkon, (7-8), 12-17. Utolsó letöltés: 2018. július 10. http://balkon.art/1998-2007/balkon02_07-08/02suvecz.html

Szilágyi V. (2010). A nemek viszonyának jövője. Egyenrangúság, nyitottság, önmegvalósitás. Budapest: Háttér.

Szőcs, I. (2008). Ciki, camp - giccs? Helikon, március 25 .

\section{Absztrakt}

Az utóbbi évtizedekben egyre nagyobb fokú figyelem irányul a férfi és női szerepek és az ezekhez kapcsolódó társadalmi elvárások kulturális meghatározottságára. Legmarkánsabban a gender- és queer-elméletek mutattak rá arra a jelenségre, hogy a tradicionálisan férfiasnak és nőiesnek minősített viselkedés nem velünk született, hanem a szociokulturális körülmények, a szükebb és tágabb környezetünk és a társadalmi elvárások hatására alakul ki. A hagyományos nemi szerepek közötti határok lebontása pedig sajátos vizuális kódokat eredményez. 